Andrzej Bonasewicz

\title{
CHANGES IN SPATIAL STRUCTURE OF VENEZUELA'S ECONOMY
}

Spatial structure of Venezuela's economy shows large disproportions - both with regard to sectors as well as regional-which, despite attempts at their reducing, are continuously growing.

The existing spatial dichotomy has its roots in the colonial period. Creation of an administrative centre of the colony contributed to concentration of the population and economic activities in the vicinity of the capital. The economic activities gave rise to the central region, concentration of power and decisions as well as subordination of peripheral regions. The spatial dualism was further intensified in the 19th and 20th centuries after gaining independence by Venezuela. The regional dichotomy was favoured by the economy of the enclave type based on $\mathrm{mi}$ ning of crude oil and iron ore which was controlled by foreign monopolies and destined mainly for exports. The income from the export of raw materials was partly used to cover needs of the central region and partly taken abroad. In effect, there arose strong dependence of peripheral regions on the central region, and of the central region on foreign centres which was typical of the system of dependent capitalism.

The central region in Venezuela covers the area of $20,130 \mathrm{sq} \mathrm{km}$, i.e. $2.34 \%$ of the area of the country and includes the Federal District and the states of Miranda, Aragua and Carabobo situated in the north of the country, on the Caribbean Sea. The main centre of the central region is the metropolitan area of Caracas and towns having over 20 thousand inhabitants. The towns form a streak of settlements along the highway La Guaira - Maracay - Valencia - Puerto Cabello. That streak is a central axis of development, with all-round developed economic activities.

Peripheral regions of Venezuela are differentiated with regard to development possibilities. The first group is composed of areas of new natural resources - the states of Zulia and Anzoategui where crude oil 
is excavated and Bolivar where iron ore is mined and the areas of agricultural colonization - Barinas and Portuguesa. These states are charasterized by an increase of income per head, increase of employment and immigration of population.

The second group of peripheral states are stagnation areas, developing slowly and characterized by emigration of population. Here belong the states of Lara, Falcon, Nueva Esparta and Maracay. They possess certain natural resources but they lack capital and technology. Their development is very one-sided, and to a great extent conditioned by potential of the internal market and vicinity of production to marlsets.

The third group of peripheral states are depression areas, with very low income per head, with emigration and traditional social structures. The lack of natural resources, suitable working force, capital and technology hinders their development. Fiere belong the states of Apure, Cojedes, Guarico, Trujillo, Merida, Tachira, Monagas, Sucre and the territories of Amazonas and Delta Amacuro.

In order to co-ordinate more hamonious development of economy, "Cordiplan" (Oficina Central de Coordinación y Planificación), Central Office for Co-ordination and Planning, was created in 1958. The Office prepared plans of development for sectors of the economy covering a few years. Those were imperative recommendations for the state sector and indicative - for the private one. Much stress was put on regional aspects of development; in effect, starting from 1960, autonomous institutions were established to programme regional development. In 1969 the country was divided into 8 administrative regions in order to "stimulate accelerated and harmonious development"; each of the regions had an institution for regional planning. They were the following: 1) Capital (metropolitan area of Caracas, the Federal District, State of Miranda and Federal Dependences),

2) Central (States of Aragua, Carabobo, Cojedes, Guarico),

3) Centro-Occidental (States of Falcon, Lara, Portuguesa, Yaracuy without the district of Sucre and the municipality of Guanare of the State of Portuguesa),

4) Zuliana (State of Zulia),

5) Los Andes (States of Barinas, Merida, Tachira, Trujillo and the municipality of Guanare and the district of Sucre (state of Portuguesa) and the district of Paez (state of Apure),

6) Sur (State of Apure without the district of Paez, the district of Cedeño of the state of Bolivar and the territory of Amazonas),

7) Nor-Oriental (States of Anzoategui, Monagas, Nueva Esparta and Sucre), 
8) Guayana (State of Bolivar without the district of Cedeno and the territory of Delta Amacuro).

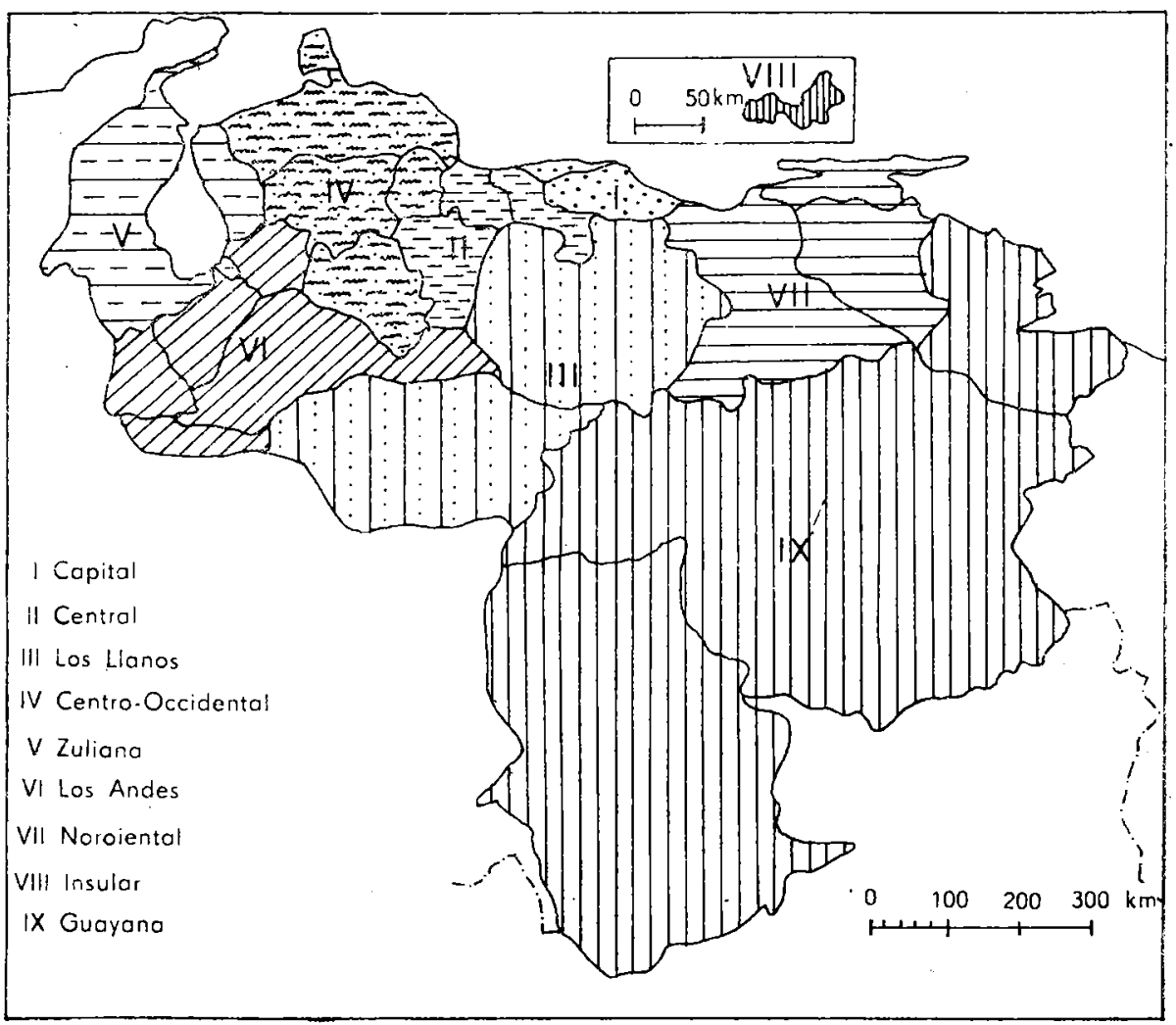

Fig. 1. Planning regions of Venezuela (1969)

In 1980, a new regionalization of the country was done for the purposes of regional development, being a correction of the previous division. The country was divided into 9 regions:

1) Capital (the Federal District and the state of Miranda),

2) Central (states of Aragua, Carabobo and Cojedes),

3) Llanos (states of Guarico and Apure without the district of Paez),

4) Centro-Occidental (states of Falcon, Lara, Portuguesa and Yaracuy),

5) Zuliana (state of Zulia),

6) Los Andes (states of Barinas, Merida, Tachira, Trujillo and the district of Paez of the state of Apure),

7) Nor-oriental (states of Anzoategui, Mongas, Lara), 
8) Insular (state of Nueva Esparta nad Federal Dependences),

9) Guayana (state of Bolivar and the territories of Amazonas, Delta Amacuro).

Each of the regions had an institution for regional planning. Best known is the activity of CVG (Corporación Venezolana de Guayana) Corporation of Venezuelan Guyana, aiming at developing the region on the basis of high-grade iron ore mined opencast and of production of hydro-energy from a hydro-electric power station on the Caroni River. The iron- and steelworks built in Puerto Ordaz became the biggest industrial plant in the country. The town of Ciudad Guayana was to become the centre of growth, activating the area of under-developed periphery due to development of an industrial complex. However, the planned centre did not activate Guyana as much as foreseen in the plan. Its activity was noticed much more in the central region than in Guyana. This was caused by one-sided development of production, being significant for the central region and abroad and only to a slight degree for Guyana. Investments financed partly by the government with a large share of foreign capital and small share of private local capital were dependent on abroad. Lack of suitable infrastructure in the region caused that effects of the investments were of local character. Too little attention was paid to development of agriculture which resulted in food shortage.

Similarly, activities of other organizations for regional planning outside the central region had little impact on the peripheral regions. Rear sons were similar to the ones in the Guyana region. A relatively low attractiveness of centres of growth created in the under-developed regions with simultaneous high attractiveness of the central region was the reason for increasing the gap between the regions.

In the field of changes of economic structures, in the period 19611971 the policy of import substitution was adopted which was a motive of many political and economic decisions. Basing on this, industrialization of the country was started by becoming independent on the import of industrial goods. This policy was the effect of decreasing export stimuli and increasing home demand for consumer goods. That was possible due to a certain consolidation of the internal market and growth of income per head from US $\$ 1,779$ in 1960 to US $\$ 2,296$ in 1970. The policy of substitution industrialization was realized by the state and private sectors and was connected with reduction of oil investments. Transformation of the industrial profile of the economy was started with modernization of old traditional branches (foodstuffs and textile industries) and appearance of new plants of chemical industry. 


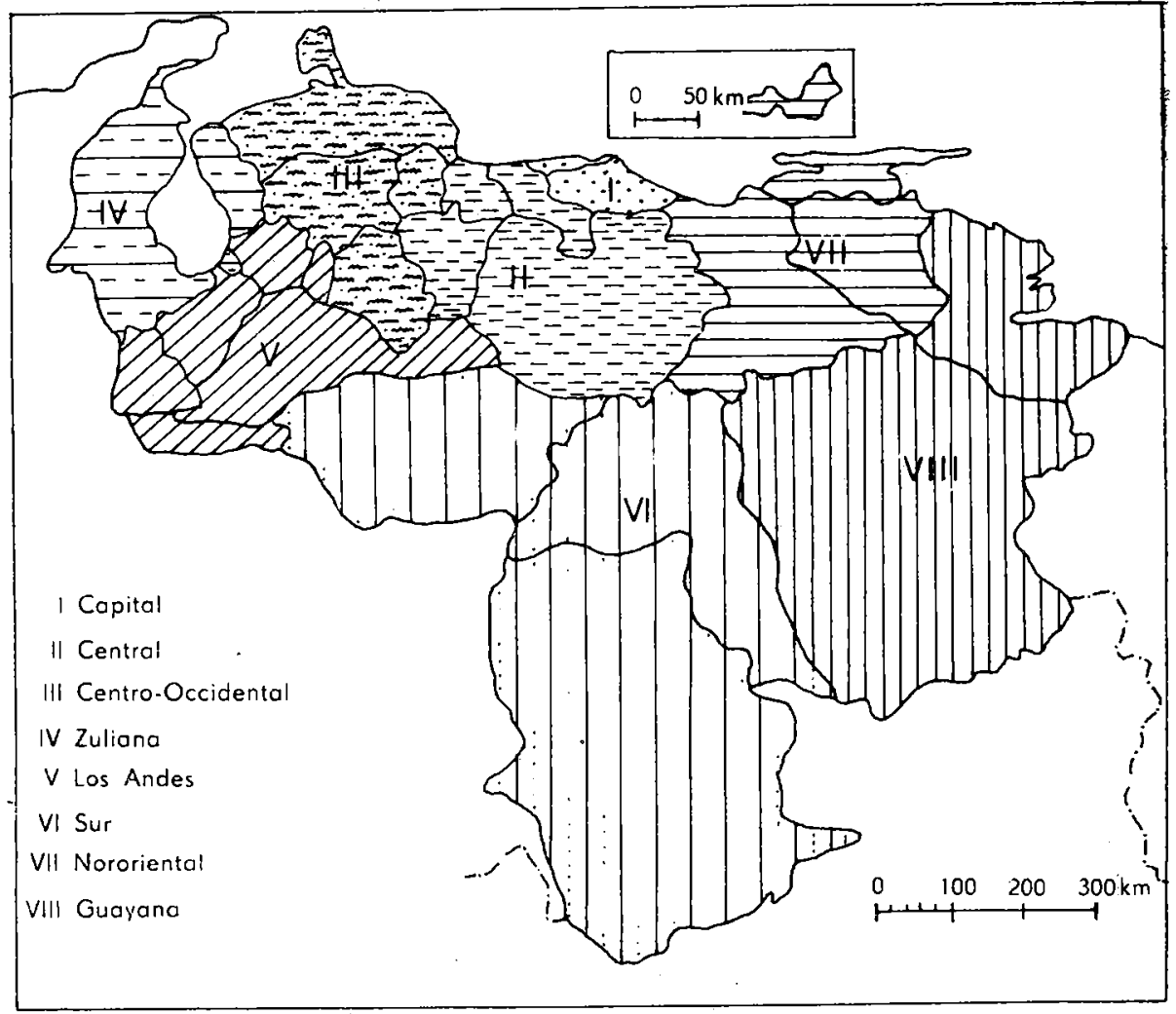

Fig. 2. Planining regions of Venezuela (1980)

refinement of crude oil and paper industry. The new plants adopted foreign technology from the developed countries; most often they used semiproducts and often imported raw materials. In effect, this policy caused various economic, social and political consequences, connected with dependent capitalism.

Spatial effect of the policy of import substitution was concentration of population and economic activity in the central region. This was caused by 'good transportation infrastructure permitting importation of raw materials from abroad and peripheral regions, accumulation of labour force as well as concentration of population with higher purchasing power. Technological, and not institutional factors were decisive with regard to industry localization. It was located along the axis Caracas - Maracay - Valencia, playing decisive role in spatial organization of the country. Vicinity of the capital, location along the Pan-American highway and convenient access to the ports of La Guaira 
and Puerto Cabello were the decisive elements in development of industry in this area.

$80 \%$ of production was directed to the central region market, although its development depended on raw materials coming from the peripheral regions and was financed by them to a great extent. Investment policy clearly favoured the central region which had almost $80 \%$ of investments in 1976 . This region was inhabited by $35 \%$ of Venezuela's population compared to $26 \%$ in 1950 . Favouring the central region was manifested in a more drastic form in financial policies of the government. The region supplied about $25 \%$ of total income to the state budget and received $92 \%$ of the government budget expenses. Simultaneously, the region of Zuliana supplying $53 \%$ of total income to the state budget, received only $2 \%$ of funds from the budget. This shows high share of peripheral regions in financing development of the central region.

Venezuela's economy was greatly affected by the world oil crisis in 1973 which brought the country enormous income caused by growth of prices for oil - the basic export commodity. This permitted the realization of many investment projects and nationalization of iron ore and earth gas mining in 1975 and crude oil in 1976. In 1973 Venezuela joined the Andes Group, a regional organization aiming at accelerating economic development through economic integration of member-countries. This facilitated change of development model by Venezuela, i.e. abandonment of import substitution for development of regional co-operation. Foreign investments decreased whereas credits granted to Venezuela by developed countries grew. This resulted in growth of external indebitedness from US\$ 924 million in 1970 to US\$1,393 million in 1975.

Tendencies of regional development in the period 1971-1981 were similar to the preceding decade. In 1977 the central region was inhabited by $37 \%$ of the country's population. Employment in industry was in 1975 twice higher than the country's average and amounted to about $30 \%$. Proportional share of the metropolitan area of Caracas in industry employment decreased and importance of nearby towns on the transportation axis Tejerias - Puerto Cabello increased. This was the effect of the policy of deglomeration of the capital through hindering investments in its area. However, industrial investments in the central region, especially in Maracay and Valencia, still prevailed. Outside the central region the town of Barquisimento showed quick growth; the town was situated in the Centro-Occidental region between the oil region of Zuliana and the central region. The growth should be explained 
by convenient location between mining and industrial regions, having relatively good transportation infrastructure.

In the decade $1971-1980$ a significant drop of growth rate of the global product from $6.6 \%$ p.a. in the period $1970-1975$ to $5 \%$ in the period 1976-1980 took place. From 1977 onwards, Venezuela had adverse balance of foreign trade. Its investment expenses grew in particular. In 1979 investments amounted to $34.1 \%$ of the global product. External indebtedness grew to US $\$ 10,239$ million in 1979 and the debts constituted $29.9 \%$ of the global product. Capital accumulated in the period of oil prosperity was quickly spent. Consumer prices began to grow rapidly and if they rose by $5.7 \%$ yearly in the period $1971-$ -1975 , the growth was $23.1 \%$ in the years 1976-1980. Absolute drop of state savings took place.

Decrease in oil prices in the 1980 s resulted in reduction of income of the country, whose economy is based on exportation of this raw material. External indebtedness amounted to US\$36 billion in 1982. Devaluation of the local monetary unit in relation to the dollar took place several times. Imports were reduced, which resulted in increasing of unemployment and worsening of material situation of the population.

The reasons for the crisis situation were both external and internal. The external ones, connected with the system of dependent capitalism, caused a drop of oil prices in the international markets. Venezuela, which based its trade in $90 \%$ on the export of oil was affected by this fact very severely. Simultaneously, high dependence on the import of foodstuffs with underdeveloped local agriculture made taking credits necessary.

The internal reasons were connected with enormous explosion of urban population which in 1980 concentrated $85 \%$ of the country's population 'with relatively low employment in industry and very high in services. The other reason were large regional disproportions in development and dependence of peripheral regions on the central one.

Effects of the crisis of the 1980s were perceptible both in the global scale of the country as well as regional. The rate of growth of the global product in those years dropped to $2 \%$ with almost $3 \%$ growth of population, which caused an absolute drop of income per head in Venezuela.

In regional scale the crisis had the most severe impact on peripheral regions. Regional centres of growth artificially stimulated to development were not able to survive the worsening economic situation. 
Descrease in demand for raw materials from those regions resulted in a drop of prices and, subsequently, a drop of regional income. Worsening of situation in those regions resulted in growth of emigration to the central region and abroad. The central region, which was best developed, was affected by the crisis in a less severe form. Natural centres of growth had the strength to overcome to some extent the pressure of the crisis situation. This fact caused further intensification of the gap between the central region and the peripheral ones. All attempts at stimulating regional economy through the institutions for regional planning appeared to be too weak in view of economic difficulties on the global scale. In the present situation nothing points to more harmonious development of Venezuela's peripheral regions, affected more by the crisis than other countries of the continent due to one-sided development of the economy and high economic and social differentiation of the country.

Changes in spatial structure of Venezuela's economy can only occui together with a change of the system of dependent capitalism and putting an end to external and intennal dependence of regions of the country. 